\title{
An experimental study on the Sleep Cycle under sleep deprived condixions using heart rate analysis.
}

\author{
心拍変動からみた断眠負荷のSleep Cycleへの影響
}

\author{
Kazuki FURUICHI, Takahito KO-OU, JUn TAKAHASHI, Kiyoyuki YAMAZAKI, \\ Katsuro OKAMOTO and Kenji IKEDA \\ Dept.of Bio-Medical Engineering , \\ School of High-Technology for Human Welfare, Tokai University \\ 317 Nishino, Numazu ,Shizuoka, 410-03 \\ TEL:81-559-68-1211(EX.4415) ,FAX:81-559-68-1156 \\ ( Accepted for publication 8 November 1996 )
}

To investigate detailed characteristics of human sleep cycle, all night polysomnograms were recorded in healthy and sleep deprived subjects. R-R interval series extracted from the ECG data were analysed using FFT. Estimated low and high frequency components of R-R power spectra were evaluated. Specific change of autonomic function during sleep was observed in sleep deprived subjects.

Keywords : frequency analy, sleep deprivation, polysomnogram

\section{INTRODUCTION}

心拍変動の性質を定量化するために心電図のR波 と次拍のR波との時間間隔をサンプルした心電図 のR-R 間隔系列は、Sleep Cycle と自律神経系の変 化を反映するといわれている。R-R間隔系列のスペ クトル解析から得られた低周波数成分及び高周波 数成分は、自律神経機能を効果的に評価できるこ とが多くの研究により示されている。現代社会で は、生活上昼夜の区別が希薄になってきており 徹夜（断眠）や、睡眠時間の減少はさまざまな 影響をもたらすと考えられている。1,2 本研究 では、生体リズムの詳細な構造を分析する目的で、 心電図、䏚波、眼球運動、筋電図を夜間 8 時間にわ たり測定し、健常被験者における断眠時 (64時間) と自然睡眠時について比較検討したので報告する。

\section{EXPERIMENTAL}

実験は、健常成人男性5名（年齢 $18 \sim 22$ 歳)を被験者とし、自然睡眠と断眠（64時間） 後の睡眠について測定した。測定はシールドルー
厶内で、AM $0: 00 \sim A M 8: 00$ まで連続的 に行った。測定項目は両耳架を基準とした単極 導出脳波(EEG)を 2 チャンネル $(\mathrm{Cz}, \mathrm{Pz})$ 、心電図 (ECG)、水平および垂直眼球運動(EOG)、オト ガイ筋筋電図(EMG)である。各指標は汎用脳波 計（日本電気三栄(株)製）を用い増幅し、AD

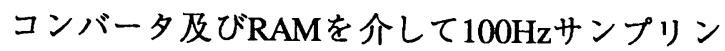
グ周波数、精度は14bitでハードディスクにディ ジタル記録した。

次に、心電図(ECG)のR-R間隔を測定し、心 拍数 $(\mathrm{HR})$ を求めた。心拍数 $(\mathrm{HR})$ を 2 分毎に等間 隔で標本化した後にFFTの計算をし、スペクト ル解析を行った。また心電図(ECG)のR-R間隔 のスペクトル解析データのHF成分パワーは副 交感神経系支配の影響を反映し、LF成分のパ ワーとLF/HF比が交感神経支配の影響を反映さ れている。この周波数帯域を採用して心拍変動 のパワースペクトル解析を行った。睡眠段階、 眼球運動および筋電図は 30 秒を 1 ページとして、 
(a)

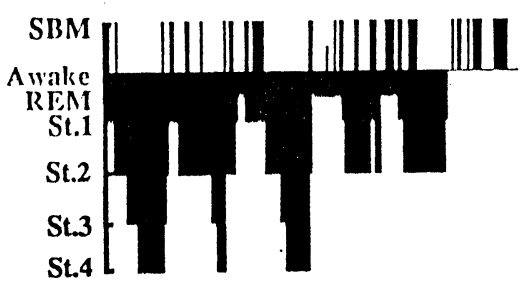

(b) $\left(\times 10^{3}\right)$

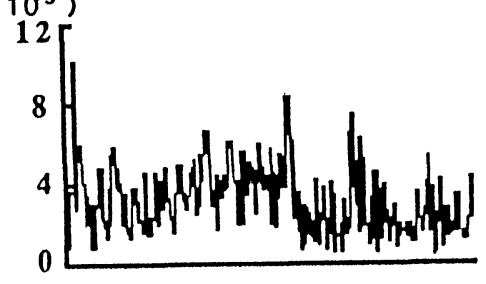

(c)

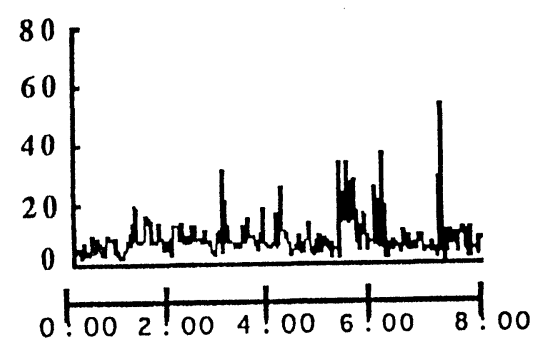

FIG.1-1.Sleep Diagram and autonomic profiles(b),(c) under Control (b):HF,(c): $\mathrm{LF} / \mathrm{HF}$ component of R-R spectra.

Rechtschafeen\&Kalesの基準に基づいた視察によ り睡眠段階を判定した。この睡眠段階の判定を 基に作成したポリグラフとスペクトル解析デー 夕を比較、検討した。

\section{RESULTand DISCUSSION}

Figure1-1とFig.1-2は、自然睡眠時(Control)と断 眠後の睡眠(Sleep Deprived)についてそれぞれ Sleep diagram (a)、HF成分パワー(b)、LF/HF比 (c)を示した。Control とSleep Deprivedを比較す ると Fig.1-2(a)では 1 周期目、 2 周期目のSleep Cycleの区別がなくなりSt.2の出現の割合が非常 に多くなっている。また、St.1の出現割合が非 常に少なくなっているため睡眠深度が浅い分睡 眠時間が長くなるのではないかと思われる。 Figure1-2(b)においては、HF成分パワーが低い值 を示し自律神経系のうち副交感神経系が沈静化 していると推測されるが、Fig.1-2(c)において

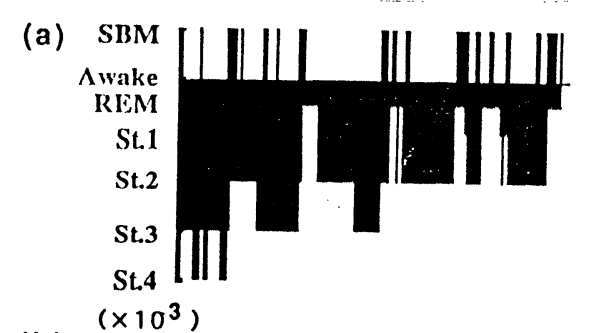

(b)

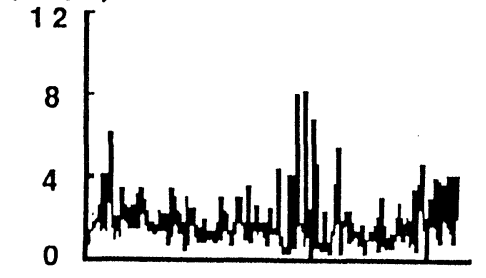

(c)

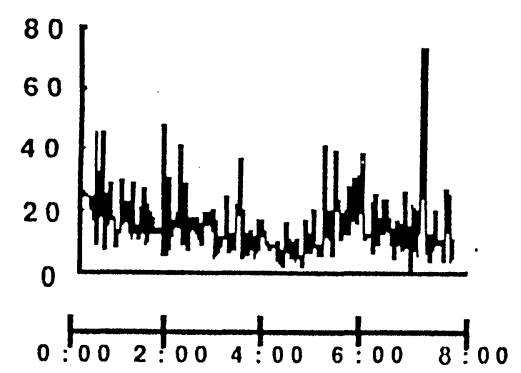

FIG.1-2.Sleep Diagram and autonomic profiles (b), (c) under Slecp Deprived (b):HF (c): $\mathrm{LF} / \mathrm{HF}$ component of $\mathrm{R}-\mathrm{R}$ spectra.

はLF/HF比が高い值を示し同じ自律神経系では あるが交感神経系は逆に附活されているようで ある。

以上のことょり脳波判定における睡眠ポリグ ラフィーのstage判定と心電図のR-R 間隔の周波 数解析では、断眠時と比較してみると異なる情 報が含まれる可能性が示唆された。

\section{REFERENCES}

1 J.Takahashi,T.aiba,M.Sugimoto,K.Yamazaki and K.Okamoto:A study on quantitative of the sleep cycle journal of Aduvanced Science,Val.8,No.1\&2 1996.

2 S.Saido,K.Ohno,T.Aiba,K.Hoshiai,J.Takahashi and K.Okamoto:A study on rerationship batween sleep pattern and psychological task performance using polysomnography, The japanese journal of Ergonnomics,Val.32,2-D-14,1996.

'96 SAS Intelligent Symposium 